\title{
Length-Weight Relationships of Brown-Marbled Grouper Epinephelus fuscoguttatus Forsskål, 1775 in Bobong Taliabu Waters of North Maluku, Indonesia
}

\author{
Umar Tangke ${ }^{1, *}$, Frentje Dusyan Silooy ${ }^{2}$, Rochmady $^{3}$, Fikri Rizky Malik $^{4}$, Susiana $^{5}$ \\ ${ }^{I}$ Department of Fisheries Processing Technology, Faculty of Agricultural, Universitas Muhammadiyah Maluku Utara, \\ Ternate, North Maluku, Indonesia \\ ${ }^{2}$ Departement of Fisheries Recources Utilization Faculty of Marine Science and Fisheries, University of Pattimura, \\ Ambon, Indonesia \\ ${ }^{3}$ Department of Aquaculture, Wuna Agricultural Science University, Raha, Southeast Sulawesi, Indonesia \\ ${ }^{4}$ Department of Fisheries Recources Utilization, Faculty of Agriculture, University of Khairun, Ternate, Indonesia \\ ${ }^{5}$ Department of Aquatic Resources Management, Faculty of Fisheries and Marine Science, Raja Ali Haji Maritime \\ University, Tanjungpinang, Indonesia \\ "Corresponding author. Email: umbakhaka@gmail.com
}

\begin{abstract}
Length-weight relationship (LWR) species Epinephelus fuscoguttatus Forsskål, 1775 by gender (male and female) were collected from September 2016 to June 2017 in Bobong Taliabu waters, North Maluku, Indonesia. Fish captured using bottom trap, size $80 \times 60 \times 35 \mathrm{~cm}$ with mesh size $5 \mathrm{~cm}$. LWRs of significant male and female E. fuscoguttatus $(\mathrm{P}<0.05)$ were calculated as $\mathrm{W}=0.0098 \mathrm{~L}^{3.1475}\left(\mathrm{r}^{2}=0.9252\right), \quad \mathrm{W}=0.0752$ $\mathrm{L}^{2.5030}\left(\mathrm{r}^{2}=0.9029\right)$, and $\mathrm{W}=0.9987 \mathrm{~L}^{1.6789}\left(\mathrm{r}^{2}=0.9093\right)$ for both. This study recorded the new maximum length by sex of E. fuscoguttatus.
\end{abstract}

Keywords: grouper, length-weigth, Epinephelus fuscoguttatus

\section{INTRODUCTION}

Length-weight relationship (LWR) is the basis of the biological parameter to be an important source of information in the assessment of fishery resources (Froese, Tsikliras, \& Stergiou [1], Tangke et al [2], Tangke et al. [3]. LWR obtained information about fish growth conditions so as to determine the growth pattern (i.e., allometric vs. isometric growth) Richter et al. [4], VegaCendejas et al. [5]. In turn, LWR is used for comparative growth studies by Tangke et al. [6], Froese \& Pauly,[7], Ricker [8]. In addition, LWR can convert length to weight and vice versa, providing insight into fish ecology by Froese [9], as well as having many important applications in fisheries management by Pauly [10], Rochmady \& Susiana [11].

Besides, LWR is used for many studies of fisheries biology, i.e., total biomass, fish conditions (overweight, food and reproduction), age structure, inter-regional growth rate, regional comparison of fish life history and specific species, Farooq et al. [12], Hashim et al. [13], Özdemir et al. [14]. Environmental suitability, Froese et al. [1], Jellyman et al. [15], Le Cran et al. [16], Reñones et al. [17], significant to develop conservation strategies fish and ensure sustainable development, Castilla [18], Patanda et al. [19]. However, LWR analysis is important to pay attention in fish gender. Nevertheless, despite having different applications, LWR data for many species of fish worldwide is still insufficient, Froese \& Pauly [20].
The north coast sea of North Maluku are considered as one of the diversity hotspots of fish in the Banda Sea. Dalzell \& Pauly, [21], Hariey \& Baskoro, [22]. The waters of Bobong Taliabu North Maluku are similar to the Bengal Sea, Bangladesh have the resources of fish with high levels of diversity, Hanif et al. [23]. The waters of Bobong Taliabu North Maluku and its surroundings are abundant with ichthyofaunal diversity, one of which is Perciformes species (E. fuscoguttatus). This study aims to analyse LWR species E. fuscoguttatus by gender (male and female).

\section{METHOD}

Specimens are collected by monthly from September 2016 to June 2017 in the waters of Bobong Taliabu $\left(02^{\circ} 02^{\prime} 09.568^{\prime \prime} \mathrm{S}-124^{\circ} 23^{\prime} 11.473^{\prime \prime} \mathrm{E}\right)$ North Maluku, one of the largest waters in North Maluku, Indonesia. The sampled fish is taken by using a "bottom trap" size specification (80 x $60 \times 35 \mathrm{~cm}$ ) the slit size is $5 \mathrm{~cm}$ with the help of local fisherman. The fish samples are identified against the species level, and the scientific name for each species was checked against FishBase, Froese \& Pauly, [20]. Specimens were identified on the spot and sorted by gender. The total length (TL) and body weight (BW) specimens were measured with a precision of $0.1 \mathrm{~cm}$ and $0.01 \mathrm{~g}$, respectively. Length-weight relationship $\left(\mathrm{W}=\mathrm{a} \mathrm{L}^{\mathrm{b}}\right)$ is estimated using a linear regression equation of $\log$ transformation. Le Cren, [16]: $\log (\mathrm{W})=\log (\mathrm{a})+\mathrm{b} \log$ $(\mathrm{L})$, where $\mathrm{W}$ is the total wet weight $(\mathrm{g}), \mathrm{L}$ is the total length $(\mathrm{cm}), a$ is the intercept, and $b$ is the slope. The 
regression parameters ( $\mathrm{a}$ and $\mathrm{b}$ ) at $95 \%$ confidence intervals (CI) and correlation coefficient values $\left(\mathrm{r}^{2}\right)$ (Froese, [9]). Prior to regression, was performed a log-log plot of length and weight relationships to eliminate extreme imaging (Froese et al., [1]). All calculations and statistical analysis using Excel 2013.

\section{RESULTS AND DISCUSSION}

The statistical summary of sex, sample size $(\mathrm{N})$, size range: length $(\mathrm{cm})$ and weight $(\mathrm{g})$ minimum and maximum, LWR parameters (a and b) at 95\% confidence intervals (CI) and correlation coefficients $\left(\mathrm{r}^{2}\right)$ in Table 1 . The regression parameters (b) and the correlation coefficient $\left(\mathrm{r}^{2}\right)$ are respectively in the range of $3.1299-3.1651$ and $0.9155-$ 0.9572 for males, ranging from 2.4788-2.5272 and 0.86880.9691 for females, and ranged from 1.6579-1.7000 and 0.9093 for the whole.

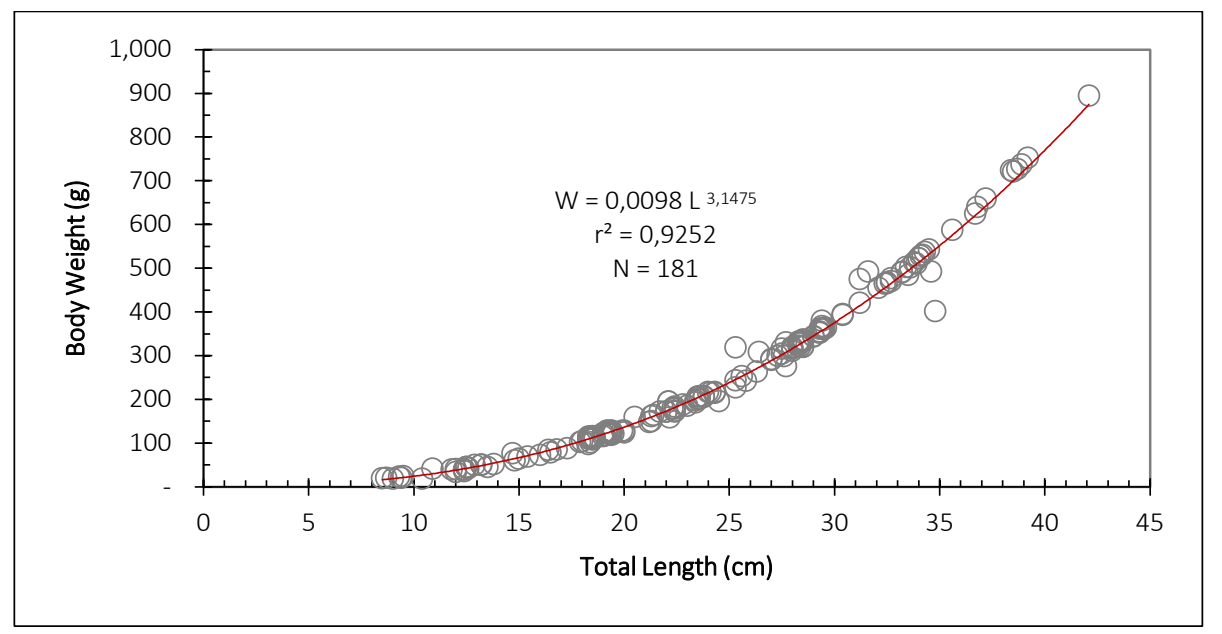

Figure 1. LWR of Brown-Marbled Grouper in Bobong,

Table 1. Descriptive statistics and LWRs parameters for Epinephelus fuscoguttatus captured by monthly from Bobong Taliabu waters of North Maluku, Ternate, Indonesia.

\begin{tabular}{|c|c|c|c|c|c|c|c|c|c|c|c|}
\hline \multirow[b]{2}{*}{ Month } & \multirow[b]{2}{*}{ Sex } & \multirow[b]{2}{*}{$\mathbf{N}$} & \multicolumn{2}{|c|}{$\begin{array}{c}\text { Total Length } \\
\text { (cm) }\end{array}$} & \multicolumn{2}{|c|}{$\begin{array}{l}\text { Weight } \\
\text { (g) }\end{array}$} & \multicolumn{3}{|c|}{ Regression parameters } & \multirow[b]{2}{*}{$95 \%$ CI a } & \multirow[b]{2}{*}{$95 \% C I b$} \\
\hline & & & Min & Max & Min & Max & $a$ & $b$ & $r^{2}$ & & \\
\hline \multirow[t]{2}{*}{ Sep-16 } & Male & 20 & 10,40 & 36,70 & 18,73 & 624,97 & 0,0502 & 2,6244 & 0,9155 & $0,0363-0,0491$ & $2,6012-2,6475$ \\
\hline & Female & 22 & 33,40 & 44,60 & 33,40 & $1.045,08$ & 0,0875 & 2,4475 & 0,8688 & $0,0265-0,0383$ & $2,4062-2,4889$ \\
\hline \multirow[t]{2}{*}{ Okt-16 } & Male & 24 & 9,30 & 33,60 & 20,40 & 501,27 & 0,9040 & 1,7056 & 0,9327 & $0,0422-0,0536$ & $1,6814-1,7298$ \\
\hline & Female & 21 & 28,56 & 36,00 & 28,56 & 608,76 & 0,1084 & 2,3900 & 0,9142 & $0,0378-0,0509$ & $2,3709-2,4091$ \\
\hline \multirow[t]{2}{*}{ Nov-16 } & Male & 17 & 8,50 & 29,60 & 18,67 & 363,27 & 0,1037 & 2,4018 & 0,9432 & $0,0489-0,0641$ & $2,2357-2,5680$ \\
\hline & Female & 14 & 18,67 & 41,30 & 18,67 & 861,93 & 0,0661 & 2,5426 & 0,9390 & $0,0308-0,0425$ & $2,5336-2,5515$ \\
\hline \multirow[t]{2}{*}{ Des-16 } & Male & 12 & 10,90 & 38,90 & 33,97 & 736,63 & 1,0749 & 1,6367 & 0,9385 & $0,0311-0,0448$ & $1,5805-1,6930$ \\
\hline & Female & 18 & 10,40 & 41,30 & 24,13 & 861,94 & 0,0642 & 2,5532 & 0,9267 & $0,0307-0,0414$ & $2,5442-2,5622$ \\
\hline \multirow[t]{2}{*}{ Jan-17 } & Male & 16 & 12,40 & 38,50 & 39,30 & 721,14 & 0,0576 & 2,5847 & 0,9538 & $0,0325-0,0419$ & $2,5781-2,5913$ \\
\hline & Female & 17 & 10,00 & 47,30 & 17,94 & $1.215,83$ & 0,0578 & 2,5848 & 0,8961 & $0,0255-0,0373$ & $2,5697-2,5999$ \\
\hline \multirow[t]{2}{*}{ Feb-17 } & Male & 19 & 12,90 & 35,60 & 49,44 & 587,77 & 0,0715 & 2,5281 & 0,9424 & $0,0342-0,0441$ & $2,5046-2,5516$ \\
\hline & Female & 16 & 10,70 & 40,70 & 21,10 & 912,89 & 0,0555 & 2,5967 & 0,8991 & $0,0280-0,0414$ & $2,5720-2,6213$ \\
\hline \multirow[t]{2}{*}{ Mar-17 } & Male & 16 & 16,50 & 42,10 & 78,90 & 894,29 & 0,0591 & 2,5765 & 0,9499 & $0,0273-0,0356$ & $2,5677-2,5853$ \\
\hline & Female & 16 & 12,20 & 42,50 & 62,17 & 924,89 & 0,1441 & 2,3158 & 0,9267 & $0,0267-0,0369$ & $2,2886-2,3430$ \\
\hline \multirow[t]{2}{*}{ Apr-17 } & Male & 17 & 12,40 & 33,20 & 39,30 & 492,18 & 0,0791 & 2,4898 & 0,9340 & $0,0376-0,0505$ & $2,4645-2,5151$ \\
\hline & Female & 16 & 13,40 & 32,00 & 50,14 & 448,79 & 0,0717 & 2,5149 & 0,9691 & $0,0399-0,0490$ & $2,5037-2,5260$ \\
\hline \multirow[t]{2}{*}{ Mei-17 } & Male & 21 & 12,00 & 36,80 & 39,97 & 639,92 & 0,6203 & 1,8438 & 0,9464 & $0,0362-0,0455$ & $1,8229-1,8646$ \\
\hline & Female & 17 & 12,70 & 33,40 & 45,55 & 497,89 & 0,0872 & 2,4502 & 0,9306 & $0,0352-0,0476$ & $2,4124-2,4880$ \\
\hline \multirow[t]{2}{*}{ Jun-17 } & Male & 18 & 12,60 & 39,20 & 42,03 & 752,545 & 0,0643 & 2,5549 & 0,9572 & $0,0308-0,0386$ & $2,5454-2,5643$ \\
\hline & Female & 14 & 14,60 & 36,70 & 52,20 & 665,45 & 0,0710 & 2,5243 & 0,9456 & $0,0325-0,0441$ & $2,4991-2,5494$ \\
\hline \multirow[t]{3}{*}{ Overall } & Male & 181 & 8,50 & 42,10 & 18,67 & 894,29 & 0,0098 & 3,1475 & 0,9252 & $0,0381-0,0414$ & $3,1299-3,1651$ \\
\hline & Female & 171 & 9,00 & 47,30 & 17,94 & $1.215,83$ & 0,0752 & 2,5030 & 0,9029 & $0,0329-0,0364$ & $2,4788-2,5272$ \\
\hline & Both & 352 & 8,5 & 47,3 & 17,94 & $1.215,83$ & 0,9987 & 1,6789 & 0,9093 & $0,0355-0,0380$ & $1,6579-1,7000$ \\
\hline
\end{tabular}


LWRs for the species E. fuscoguttatus are reported for the umpteenth time in FishBase. This study recorded the total length (TL) and the maximum weight of E. fuscoguttatus each of $17.94 \mathrm{~cm}$ and $1,215.83 \mathrm{~g}$. All parameter estimation b during the study period was in the range of 1.63672.6244 for males, the range of 2.3158-2.5967 for females as expected. Besides that, it was found the estimated species values were within in approximate Bayesian length-weight ranges in FishBase, Froese \& Pauly, [20].

Based on the scientific literature and data from FishBase, no information was found on LWR for male and female E. fuscoguttatus. The study found a maximum total length of E. fuscoguttatus of $42.10 \mathrm{~cm}$ for males, and of $47.30 \mathrm{~cm}$ for females thus giving new total length information based on gender in FishBase. Although the sample size is large enough it covers $80 \%$ of the total known maximum length, but for this species is generally smaller than the total size of a reported total of $120 \mathrm{~cm}$. The difference in total length size may be due to the dominance of small size fish in this geographic area or environmental constraints, Rochmady \& Susiana [24], Susiana et al. [25]. The values of 'b' for this fish species have not been reported. In this study, the parameter value ' $b$ ' is within the normal range of 2.5-3.5., Froese. [9]. However, the regression parameters ' $a$ ' and ' $b$ ' may vary with sample size, different length standards, sampling season, gonadal maturity, sex, and stomach fullness, Sang \& Fotedar, [26], Siddik et al [28], Wang et al. [27]. The values of 'a' and 'b' for each species compared to the $95 \%$ confidence limit of the Bayesian value estimate of LWRs in FishBase are found as new information. In addition, this study provides new information on LWR species E. fuscoguttatus by sex.

\section{CONCLUSION}

In conclusion, the findings of this study offer new information about the biological aspects of E. fuscoguttatus species that are part of Perciformes based on their gender from the waters of Bobong Taliabu North Maluku, Indonesia that will be useful for sustainable fisheries development.

\section{REFERENCES}

$\lceil 11$ Froese. R.. Tsikliras. A. C.. \& Stergiou. K. I. (2011). Editorial note on weight-length relations of fishes. Acta Ichthvologica et Piscatoria. 41(4), 261263. https://doi.org/10.3750/AIP2011.41.4.01

「21 Tangke U.. 2014. Parameter nonulasi dan tingkat eksnloitasi ikan tongkol (Euthvnnus affinis) di nerairan Pulau Morotai. Agrikan: Jurnal Ilmiah Agribisnis dan Perikanan. 7(1):74-81. DOI: 10.29239/j.agrikan.7.1.7481 .

I31 Tangke U.. Deni S.. \& Aunaka A.. 2018a. The Influence of Using Bait Tvnes to the Number and Composition of Fishing Trans Catch in South Ternate Waters. IOP Conference Series: Earth and Environmental Science. 175(1):12231. DOI: $10.1088 / 1755-1315 / 175 / 1 / 012231$.

$\lceil 41$ Richter. H.. Lückstädt. C.. Focken. U. L.. \& Becker. K. (2000). An imnroved nrocedure to assess fish condition on the basis of length-weight relationshins. Archive of Fisherv and Marine Research. 48(3). 226-235. https://doi.org/0944-1921/2000/48/3$226 / 15.00 \$ / 0$

$\lceil 51$ Vega-Cendeias. M. E.. de Santillana. M. H.. \& Arceo. D. (2012). Length-weight relationshins for selected fish snecies from a coastal lagoon influenced bv freshwater seens: Yucatan peninsula. Mexico. Journal of Annlied Ichthvologv. 28(1). 140-142. https://doi.org/10.1111/j.1439-0426.2011.01875.x

[6] Tangke U.. Sangadii I.. Rochmadv R.. \& Susiana S.. 2018b. A nonulation dvnamic asnect of Selaroides lentolenis in the coastal waters of South Ternate Island, Indonesia. AACL Bioflux. 11(4):1334-1342.

171 Frnese. R. \& Paulv. D. (2000). FishBase 2000: concepts, design, and data sources. Manila: ICLARM.

「81 Ricker. W. E. (1975). Comnutation and interpretation of biological statistics of fish ponulation. Bulletin Journal of Fish Research Board Canada. 191. 1-382. Retrieved from https://ci.nii.ac.jp/naid/10018066635/

[9] Froese. R. (2006). Cube law. condition factor and weight-length relationshins: Historv. meta-analvsis and recommendations. Journal of Applied Ichthvologv. 22(4). 241-253. https://doi.org/10.1111/j.14390426.2006.00805.x

[101 Paulv. D. (1984). Length-converted catch curve. a nowerful tool for fisheries research in the tronics (nart III: conclusion). Fishbvte. 2(3). 9-10. Retrieved from https://ideas.repec.org/a/wfi/wfbyte/38112.html

「111 Rochmadv. R. (2012). Hubungan naniang bobot dan faktor kondisi kerang lumnur Anodontia edentula. Linnaeus 1758 di pulau Tobea Kecamatan Napabalano. Kabunaten Muna. Agrikan: Jurnal Agribisnis dan Perikanan. 5(1). 1-8. https://doi.org/10.29239/j.agrikan.5.1.1-8

$\lceil 121$ Farooa. N.. Oamar. N.. Rashid. S.. \& Panhwar. S. K. (2017). Length-weight relationshin of eleven snecies of marine catfishes from the northern Arabian Sea coast of Pakistan. Chinese Journal of Oceanologv and Limnologv. $35(5)$. 1218-1220. https://doi.org/10.1007/s00343-017-6117-2

「131 Hashim. M.. Abidin. D. A. Z.. Das. S. K.. \& Mazlan. A. G. (2017). Length-weight relationshin. condition factor and TROPH of Scatonhagus argus in Malaysian coastal waters. AACL Bioflux, 10(2), 297307.

$\lceil 141$ Özdemir. S.. Sövlevici. H.. Özdemir. Z. B.. Özsandikc1. U.. \& Büvükdeveci. F. (2018). Determination of monthlv length-weight relationshins and length comnosition of whiting (Merlangius merlangus euxinus) cantured from The Black Sea Coasts (SINOP-SAMSUN). Aauatic Research, 1(1), 26-37. https://doi.org/10.3153/AR18004

$\lceil 151$ Jellvman. P. G.. Booker. D. J.. Crow. S. K.. Bonnett. M. L.. \& Jellvman. D. J. (2013). Does one size fit all? An evaluation of length-weight relationshins for New Zealand's freshwater fish species. New Zealand Journal of Marine and Freshwater Research, 47(4), $450-468$.

https://doi.org/10.1080/00288330.2013.781510

「161 Le Cren. E. D. (1951). The Length-Weight Relationship and Seasonal Cycle in Gonad Weight and 
Condition in the Perch (Perca fluviatilis). The Journal of Animal Ecologv, 20(2), 201-219. https://doi.org/10.2307/1540

$\lceil 171$ Reñones. O.. Grau. A.. Mas. X.. Riera. F.. \& Saborido-Rev. F. (2010). Renroductive nattern of an exnloited duskv grouner Eninenhelus marginatus (Lowe 1834) (Pisces: Serranidae) population in the western Mediterranean. Scientia Marina. 74(3). 523-537. https://doi.org/10.3989/scimar.2010.74n3523

「181 Castilla. J. C. (2000). Roles of exnerimental marine ecologv in coastal management and conservation. Journal of Exnerimental Marine Biologv and Ecologv. 250(1-2). 3-21. https://doi.org/10.1016/S0022-0981(00)00177-5

「191 Patanda. M.. Wisudo. S. H.. Monintia. D. R.. \& Wirvawan. B. (2017). Sustainabilitv for reef fish resource based on productivitv and susceptibilitv in Wangi-Wangi Island. Southeast Sulawesi, Indonesia. AACL Bioflux, 10(4), 861-874.

「201 Froese. R. \& Paulv. D. (2015). World Wide Web electronic nublication. Retrieved April 8, 2018, from http://www.fishbase.org.

1211 Dalzell. P.. \& Paulv. D. (1990). Assessment of the fish resources of southeast Asia. with emnhasis of the Banda and Arafura seas. Netherlands Journal of Sea Research. 25(4). 641-650. https://doi.org/10.1016/0077-7579(90)90086-V

「221 Hariev. J.. \& Baskoro. M. S. (2011). Fishing canacitv of the small-nelagic fisherv at Banda Sea. Moluccas. Journal of Coastal Development, 14(2), 115124.

「231 Hanif. M. A.. Islam. M. A.. Siddik. M. A. B.. \& Chaklader, M. R. (2018). Length-weight relationships of three estuarine fish snecies from Bangladesh. Journal of Annlied Ichthvology, 00, 1-3. https://doi.org/10.1111/jai.13707

$\lceil 241$ Rochmadv. R.. \& Susiana. S. (2014). Pendugaan stok ikan keranu (grouner) di nerairan Selat Makassar Sulawesi Selatan neriode tahun 1999-2007. Agrikan: Jurnal Agribisnis dan Perikanan. 7(2), 60-67. https://doi.org/10.29239/j.agrikan.7.2.60-67

$\lceil 251$ Susiana. S.. Niartiningsih. A.. Amran. M. A.. \& Rochmadv. R. (2017). Suitabilitv of location for restocking clams Tridacnidae in the Snermonde Archinelago. Jurnal Ilmu dan Teknologi Kelautan Tronis. 9(2). 475-490. https://doi.org/10.29244/jitkt.v9i2.19284

「261 Sang. H. M. \& Fotedar. R. (2004). Growth. survival. haemolvmnh osmolalitv and organosomatic indices of the western king prawn (Penaeus latisulcatus Kishinouve. 1896) reared at different salinities. $\begin{array}{ll}\text { Aauaculture. } & 234(1-4) \text {. } \\ \text { 601-614. }\end{array}$ https://doi.org/10.1016/j.aquaculture.2004.01.008

$\lceil 271$ Wang. C.. Xie. S.. Chang. X.-L.. \& Huang. D.-M (2015). Length-weight relationshins of five fish snecies from the Hongshui River. China. Journal of Annlied Ichthvologv. 31(6). 1180-1181. https://doi.org/10.1111/jai.12896.

5281 Siddik. M. A. B.. Chaklader. M. R.. Hanif. M. A. Nahar. A.. Ilham. I.. Cole. A.. \& Fotedar. R. (2017). Variation in the life-historv traits of a Schilbid catfish. Clunisoma garua (Hamilton. 1822) in the coastal waters of southern Bangladesh. Chinese Journal of Oceanologv and Limnologv. 35(5). 1189-1196. https://doi.org/10.1007/s00343-017-6008-6 